\section{European analogies for a liberal peace in Northeast Asia}

\section{Brendan Howe}

$\mathrm{F}$

ollowing the successful example of Europe, liberal optimism has spilled into Northeast Asian analysis with hope for the evolution of a liberal virtuous triangle of democratization, economic interdependence, and international organization. ${ }^{1}$ Yet the international environment in contemporary Northeast Asia bears a closer resemblance to that of the European interwar twenty-year crisis of liberalism rather than that of the post-second world war integration project in Europe, and thus, again, at least in this region, such optimism may be seen as premature

This article addresses first, the extent to which one should be optimistic about the liberal internationalist project in Northeast Asia following the path trodden by Europe in the second half of the twentieth century. Having examined the limitations of this analogy, the second section considers the extent to which Europe's experience of a prolonged crisis in the first half of the twentieth century is more analogous to the contemporary Northeast Asian environment. Finally, the third section assesses whether there are in fact grounds for optimism in Northeast Asia based not on the region's similarities to Europe but rather on its differences from the liberal perpetual peace prototype. The findings are that while Northeast Asia is not a zone of liberal Kantian peace based on the virtuous triangle, and despite power political challenges, a rationally and socially constructed security environment has emerged to constrain the conflictual tendencies of self-interested actors.

\section{A Northeast Asian Union?}

The European integration project was an explicit attempt to eradicate the scourge of war through the practical application of the liberal ideals of economic interdependence, international organization, and democratic peace. Building on the success of the 1951 Coal and Steel Treaty, economic interdependence and political integration were steadily expanded, culminating in the 1992 Treaty on European Union, the 1997 Treaty of Amsterdam, and the 1999 monetary union. The project has also promoted the third side of the triangle with democratic-only membership encouraging transition in Greece, Portugal, Spain, and more recent candidates from Central and Eastern Europe. Europe was also the testing ground for another new and important element of a liberal security strategy, with international norms established by 35 states participating in the Conference on Security and Cooperation in Europe (CSCE) signing the Helsinki Final Act contributing directly to the demise of communism in the former Eastern bloc. ${ }^{2}$ The following subsections address the extent
Table 1: Comparative statistics for Northeast Asian states

\begin{tabular}{|c|c|c|c|c|}
\hline & $U S A$ & Japan & Taiwan & S. Korea \\
\hline (1) & 10 & 36 & 40 & 52 \\
\hline (2) & $\$ 47,000$ & $\$ 34,200$ & $\$ 31,900$ & $\$ 26,000$ \\
\hline (3) & $307.2 \mathrm{mn}$ & $127.1 \mathrm{mn}$ & $23.0 \mathrm{mn}$ & $48.5 \mathrm{mn}$ \\
\hline (4) & $4.06 \%$ & $0.8 \%$ & $2.2 \%$ & $2.7 \%$ \\
\hline \multirow[t]{3}{*}{ (5) } & 3 China 5.6 & 1 U.S. 20.4 & 1 China 32.6 & 1 China 22.1 \\
\hline & 4 Japan 5.4 & 2 China 15.3 & 2 U.S. 12.9 & 2 U.S. 12.4 \\
\hline & & $\begin{array}{l}3 \text { S. Korea } 7.6 \\
4 \text { Taiwan } 6.3\end{array}$ & 4 Japan 6.4 & 3 Japan 7.1 \\
\hline \multirow[t]{3}{*}{ (6) } & 1 China 16.9 & 1 China 20.5 & 1 Japan 22.7 & 1 China 17.7 \\
\hline & 4 Japan 7.4 & 2 U.S. 11.6 & 2 U.S. 13.3 & 2 Japan 15.8 \\
\hline & & 6 S. Korea 4.4 & $\begin{array}{l}3 \text { China } 11.2 \\
4 \text { S. Korea } 6.6\end{array}$ & 3 U.S. 10.5 \\
\hline \multirow[t]{2}{*}{ (7) } & 1 & 19 & 35 & 40 \\
\hline & Russia & China & Mongolia & N. Korea \\
\hline (1) & 74 & 133 & 165 & 192 \\
\hline (2) & $\$ 15,800$ & $\$ 6,000$ & $\$ 3,200$ & $\$ 1,700$ \\
\hline (3) & $140.0 \mathrm{mn}$ & $1,338.6 \mathrm{mn}$ & $3.0 \mathrm{mn}$ & $22.7 \mathrm{mn}$ \\
\hline (4) & $3.9 \%$ & $4.3 \%$ & $1.4 \%$ & $\mathrm{n} / \mathrm{a}$ \\
\hline \multirow[t]{2}{*}{ (5) } & 7 China 4.5 & 1 U.S. 19.1 & 1 China 71.9 & $1 \mathrm{~S}$. Korea 45.0 \\
\hline & & $\begin{array}{l}3 \text { Japan } 8.4 \\
4 \text { S. Korea } 4.6\end{array}$ & 3 U.S. 4.8 & 2 China 35.0 \\
\hline \multirow[t]{4}{*}{ (6) } & 2. China 12.2 & 1 Japan 14.0 & 1 China 32.0 & 1 China 27.0 \\
\hline & 4 Japan 6.4 & 2 S. Korea 10.9 & 2 Russia 29.4 & 2 S. Korea 16.0 \\
\hline & 5 U.S. 4.8 & 3 Taiwan 10.5 & 3 S. Korea 7.9 & 4 Russia 7.0 (2006) \\
\hline & 7 S. Korea 4.4 & 4 U.S. 7.3 & 4 Japan 7.2 & \\
\hline (7) & 146 & 132 & 69 & 179 \\
\hline
\end{tabular}

Notes: (1) rank, GDP/capita; (2) US\$ GDP/capita; (3) population size, 2009 estimates; (4) military expenditure as percentage of GDP, 2005 or 2006; (5) rank, export partners (\% of trade), 2007; (6) rank, import partners (\% of trade), 2007; (7) world rank, Index of Economic Freedom.

Sources: All information from the CIA World Factbook except for the Index of Economic Freedom rankings, which may be found at the Heritage Foundation website http://www.heritage.org/index/rankings.aspx. 
to which each of these elements has been transferred to the Northeast Asia.

\section{Economic interdependence}

High levels of modernization are being achieved throughout the region. However, economic growth has been uneven, leading to the possibility of resentment of, and conflict between, neighbors. The United States and Japan are modern industrialized developed states, South Korea is close to achieving the same status, and China's phenomenal growth indicates it may eventually catch up. Russia has just broken into the upper-middle income bracket, while Mongolia and North Korea remain underdeveloped. (By contrast, the lowest rankings for countries in the EU are uppermiddle incomes. ${ }^{3}$ ) Globalization rankings for all Northeast Asian countries, including the United States, are very low, especially when only economic indicators are considered. ${ }^{4}$ Table 1 shows the relative importance of countries in the region in terms of population, military expenditure, and size of economies, but also the unevenness of development and modernization in the region displayed by widely divergent GDP per capita scores and ranks

Asian trade has risen, whether measured as a percentage of purchasing-power parity gross domestic product (PPP GDP) or as a percentage of GDP. Likewise foreign direct investment as a percentage of PPP GDP has risen since 2000. These measures lag behind those found in Europe. But exports within the region have increased and, within the Asia-Pacific Economic Community (APEC), now exceed the percentage of total exports shipped within EU borders. Yet those within the East Asian Economic Caucus (EAEC) remain lower. This is explained by the absence of the United States from the EAEC while it is present in APEC. Even the inclusion of China in the EAEC figures, while it is excluded from APEC measurements, is not enough to overcome this omission.

For most of the region's economies, trade within Asia is becoming increasingly important. The exception, China, however, is a large one. The region as a whole is faced with lopsided over-reliance on the U.S. market, unequal bilateral trading relationships between industrialized and emerging Asia, and also between the Chinese mega-economy and other states. This means (1) that pacific effects of intra-regional interdependence may not be felt; (2) that as rapidly developing countries fight for a share of the U.S.-American and other international markets, relations between them have the potential to deteriorate; and (3) that power relations are likely to reassert themselves. Table 2 shows that although intraregional trade now accounts for more than 50 percent of the total, EU figures are closer to 60 percent, and actually the major powers of industrial Asia trade little with each other (only 6.6 percent). ${ }^{5}$

The Northeast Asian situation is further exacerbated by a lack of free trade initiatives between any of the regional great powers. Countries in the region have far fewer cooperative economic arrangements than is the norm for economies of their scale and development, and the trading models of most of these countries are tied
Table 2: Direction of exports, share (2006) and change (from 1990)

$\begin{array}{lllllll}\begin{array}{l}\text { Exporting } \\ \text { region }\end{array} & \begin{array}{l}\text { All } \\ \text { Asia }\end{array} & \begin{array}{l}\text { Emerging } \\ \text { Asia }\end{array} & \begin{array}{l}\text { Industrial } \\ \text { Asia }\end{array} & \text { NAFTA } & \text { EU15 } & \begin{array}{l}\text { Rest of } \\ \text { the world }\end{array} \\ \text { All } & 51.9 & 42.1 & 9.9 & 20.7 & 14.2 & 13.2 \\ \text { Asia } & (9.2) & (11.7) & (-2.5) & (-6.9) & (-4.1) & (1.9) \\ \text { Emerging } & 51.6 & 40.8 & 10.8 & 20.1 & 14.6 & 13.6 \\ \text { Asia } & (4.1) & (9.8) & (-5.7) & (-4.6) & (-2.2) & (2.7) \\ \text { Industrial } & 53.1 & 46.5 & 6.6 & 22.5 & 12.8 & 11.6 \\ \text { Asia } & (16.2) & (16.9) & (-0.7) & (-8.7) & (-7.4) & (-0.1) \\ \text { NAFTA } & 19.5 & 13.5 & 6.0 & 52.5 & 14.6 & 13.4 \\ & (-5.8) & (1.0) & (-6.8) & (11.9) & (-7.4) & (1.3) \\ & & & & & & \\ \text { EU15 } & 8.2 & 6.1 & 2.2 & 9.6 & 59.2 & 23.0 \\ & (0.7) & (1.7) & (-1.0) & (1.2) & (-6.7) & (4.8)\end{array}$

Notes: Numbers in parentheses are changes in shares from 1990 to 2006; diagonal cells are intraregional trade flows; NAFTA = North American Free Trade Agreement; EU15 = Austria, Belgium, Denmark, Finland, France,

Germany, Greece, Ireland, Italy, Luxembourg, Netherlands, Portugal, Spain, Sweden, and United Kingdom

Source: IMF Direction of Trade Statistics and IMF staff calculations

more to economic nationalism and protectionism than the liberal capitalist model designed to boost integration and peace (hence the low economic freedom rankings for all but the United States in Table 1). Since China's accession to the World Trade Organization, her trading partners have become increasingly dissatisfied with its growing economic nationalism and failure to liberalize; in Japan and Korea international investment has been actively discouraged even to the extent of initiating legal procedures against foreign interests; and Russia has recently passed several laws limiting participation in its oil industry to local firms. ${ }^{6}$ Thus rapid development has not been matched by the evolution of peace-inducing interdependence in Northeast Asia. 
International organizations and institutions

European leaders are restrained by external constraints of international organizations, and the external constituency of a regional normative community. By contrast, Northeast Asia combines outstanding economic growth with minimal international organization. The needs of coexistence are provided by global organizations such as the United Nations or WTO, or bilateral agreements. Without regional organization, it is difficult for statesmen to foster a culture of common interests leading to cooperation rather than conflict. Part of the problem is historical, with the only prior experience of international organization, the Greater East Asia Co-Prosperity Sphere, established through Japanese conquest.

Because economic growth and development have been experienced in the context of a supportive transregional regime composed of the United States and global international organizations, there appears little need to change. Regional integration in Northeast Asia is viewed as unfeasible, unnecessary, unlikely, and undesirable. APEC and the ASEAN Regional Forum (ARF) processes, the Shanghai Cooperation Organization, and the Six Party Talks are the closest the region comes to international organization but each is unsuited to boosting international cooperation and regional identity.

The concept of open regionalism upon which APEC is built, means that it is too large, unwieldy, and unfocused to perform the identity-related tasks required for the creation of an organizationally constructed collective security environment. Its economic focus and voluntary commitments, make it an unsuitable mechanism for the promotion of security spillover. ${ }^{8}$ The ARF has a security focus and includes all the major players from the region, yet it has made little progress in the face of great power ambivalence. Southeast Asian origins not only could alienate Northeast Asian regimes but also, given the ASEAN emphasis on consensus, may not be productive. Furthermore, ASEAN simply lacks the resources for the task.

The Shanghai Cooperation Organization (SCO) is primarily centered on Central Asian security-related concerns. If an unstated purpose of SCO is to serve as a counterbalance to NATO and the United Staets, given their close strategic alliances with Japan and South Korea, the SCO could even further divide Northeast Asia. Advocates claim the Six Party Talks could and perhaps should evolve along the lines of the Helsinki process. ${ }^{9}$ However, a Helsinki effect is an unlikely outcome. Much of the impetus that eventually led to the Helsinki Accords came from the Eastern side of the Iron Curtain as part of a quest for legitimation. ${ }^{10}$ Neither North Korea nor China is making such overtures.

Regional integration proved possible in Europe in part due to a perceived common heritage within well-defined geographic boundaries. The socio-political hierarchies in Northeast Asia still glare at the barbarian "other" over barricades. European political forms and traditions comprise a key component of community construction. For Buzan and Segal, absent an enlightenment, Asian politics leans toward authoritarianism and sudden changes of policy, with less transparent political and economic cultures making conflict and misunderstanding among them more likely. ${ }^{11}$ This then speaks to the democratic peace.

\section{A zone of democratic peace?}

The great liberal hope for the region is that as China continues its phenomenal economic progress, a natural and inevitable by-product will be the emergence of a true Chinese civil society that in turn will press for political liberalization. ${ }^{12}$ With the United States, Japan, and South Korea already consolidated democracies a politically transformed China would not only lead to more democratic than conflictual dyads, but would also defuse the potential flash point with democratic Taiwan. Asian peoples are increasingly westernized in their outlook and their societies penetrated by western media, cultural, and economic organizations. The West can impose its wishes through control of multinational organizations transitional countries wish to join. And there is a consensual process whereby the desire to imitate a way of life associated with the liberal capitalist democracies (the wish for modernity) may undermine the social and institutional foundations of any regime perceived as incompatible with these aspirations. $^{13}$

However, Henry Nau notes that “Asia's emerging democracies suffer from deficiencies in peaceful rotation of opposing parties in power, divided and accountable institutions, and protection of civil liberties." He finds bureaucratic politics in Asian democracies to be "elitist, highly personalized, and often corrupt," with weak civil societies and institutions, subsidized and controlled media, corrupt judicial systems, brutal policing, and commonplace human rights violations. ${ }^{14}$ Russia's democracy is regressing, Mongolia's transition is fragile, and both South Korea and Taiwan are plagued by disloyal oppositions. In North Korea, Kim Jong-il's regime is likely to be replaced by another form of authoritarian government rather than democracy, and in Japan elites and a single political party exercise an inordinate amount of influence.

In China the Tiananmen Square massacre is but the most glaring symptom of stalled democratization. Tentative steps taken in Hong Kong under British rule were abruptly reversed when the territory returned to China's direct control. In 2002 the government launched an attack on the internet, attempting to restrict access and block sites. Crackdowns against the Falun Gong and other groups under Jiang Zemin's old guard have continued under the new leadership. Economic development has in some ways only strengthened authoritarian forces.

The current political and economic climate challenges the consensual process of democratic convergence. The Western way of life only exerts a positive attraction as long as it is perceived to be desirable and preferable to other alternatives. During a pronounced downturn this may no longer be the case, particularly if competition leads to a new wave of protectionism and shrinking global trade. Furthermore, promised 
benefits of democratic transition have been slow to materialize; an expectancy gap has developed within many transitional states and may, in some cases, lead to a degree of discontent sufficient to undermine or even reverse the liberalization that has already taken place. China offers an alternative center of gravity, and its "charm offensive" 15 toward its neighbors contrasts with recent unilateral, illiberal, and "charmless" U.S. policy. Hence Joshua Ramo has identified a "Beijing Consensus" which may ultimately hold more appeal than the political and economic reforms advocated by the Washington consensus, particularly in the light of the current collapse of the U.S.-led international economic system. ${ }^{16}$

A Northeast Asian Union based, like the European Union, on liberal principles is therefore unlikely to emerge, at least in the short to medium term. A number of trends in fact point to a power political future of uncertainty and conflict for the region. These are analyzed in the next section addressing the extent to which the contemporary security environment in Northeast Asia is more analogous to that of the first half of the twentieth century before the European integration project took hold.

\section{The crisis of liberalism in Northeast Asia}

When Europe experienced its twenty year crisis it was already characterized by high degrees of development and interdependence, but nevertheless was brought to war by the collapse of the liberal economic system and the re-emergence of economic nationalism in the wake of the Wall Street crash and contraction of global trade. Democratization had made great strides on the continent, with the United Kingdom and France consolidated democracies, and all other great powers transitioning toward democracy; but such was the impact of the crisis and democracy's public support so dependent upon economic performance that Hitler and Mussolini were elected in Germany and Italy, respectively, Republican Spain fell to Franco, and the prospects for democratic peace withered along with the shrinking number of democratic dyads. Hopes for peaceful resolution of disputes rested with a global body from which the world's greatest power remained aloof rather than with a regional international organization. Security arrangements still seemed to be dictated by balance of power politics or geopolitics - a struggle for hegemonic dominance between a declining naval power (Britain) and a rising land power (Germany).

Ian Bremmer and co-authors claim that the parallels of rising regional powers, territorial conflicts, and troubled bilateral relations could see Northeast Asia following a model analogous to Europe early in the twentieth century which set the continent on the road to "50 years of catastrophic violence." ${ }^{17}$ While the world is experiencing now an economic meltdown of a similar magnitude to that of the Wall Street crash, the region is entering its second such crisis within a generation. Japan, the economic powerhouse of the region, has only just recovered from a decade-long slump following the 1997-1999 Asian financial crisis, only to be faced with another manufacturing and export collapse of even greater magnitude. ${ }^{18}$ Asian stock markets are plummeting again. ${ }^{19}$ Perhaps most worrying is that intra-Asian trade is described as "entering free-fall" and therefore unable to contribute further to the pacific effects of economic interdependence. $^{20}$

The benign era of liberal "econophoria" is threatened and regional if not global stability is seen by some as hanging by a thread as it did in Europe in the 1930s. ${ }^{21}$ The collapse of the Doha round of the world trade talks and the responses to the crisis of major economies such as the Buy America clause in the U.S. financial stimulus package (even in its more diluted form) could lead to a new round of economic national and further shrinkage of global trade, and thereby a rise in conflictual forces. ${ }^{22}$ Nationalism is on the rise in Northeast Asia. All states in the region feel resentment toward and fear of the historical role of Japan, the current primacy of the United States, and the future rise of China. As can be seen from Table 3, Northeast Asia is a veritable powder-keg, with five of the world's top ten defense spenders. ${ }^{23}$

Due to its explicitly revisionist mantra, and phenomenal growth, China is seen as posing the greatest threat to regional security. Learning from the 1990-91 Gulf war, China embarked on a major military modernization program, acquiring from Russia or developing itself, in-flight refueling technology, modern weapons, aircraft carriers, new destroyers, attack submarines, and ballistic missile submarines, new radar and radar-guided missiles, a new multi-role fighter, stealth technology, and is expanding and improving its strategic nuclear missile force. Steven Mosher believes that China deserves a reputation for bellicosity, finding a propensity for violence greater than that of other states (76.9 percent of the time in its international crises, compared to 53.5 percent for Muslim states, 28.5 percent for the USSR, and 17.9 percent for the United States). ${ }^{24}$

After a decade of rapprochement North and South Korea are once more rattling sabres at each other. The 2008 elevation to office in South Korea of a conservative president from the Grand National Party, Lee Myung-bak, has led to an end to the Sunshine Policy of constructive engagement and unconditional economic aid for the North. In response, North Korea has announced that "the group of traitors has already reduced all the agreements reached between the North and the South in the past to 
dead documents," relations have reached "the brink of war" and that therefore the North no longer considers itself bound by such agreements. ${ }^{25}$

Alan Dupont notes that not only is Japan moving away from its pacifist past toward a more outward-looking security posture characterized by a greater willingness to use the Self Defense Forces in support of Japan's foreign policy, but also that this shift is gaining momentum, represents a watershed in Japan's postwar security policy, is palpable, irreversible, and broadly based, with younger people being more inclined to support revising the constitution than their parents. ${ }^{26}$ Contemporary Sino-Japanese relations have been compared with the Anglo-German rivalry prior to world war I. ${ }^{27}$

In geopolitical terms we are entering a period of uncertainty and instability, similar to that of a hundred years ago when the declining seapower-based world leader (then Great Britain, now the United States) is challenged by an ascending continental landpower. The asynchronous relation of power deconcentration and reconcentration cycles, between the world system as a whole and the European subsystem, has provided the impetus for previous confrontations of this sort. However, it is now in the Asian regional subsystem where we see asynchronicity, the concentration of power in Chinese hands going against the global trend of deconcentration. Geopolitical prediction would see war between a rapidly rising China and declining United States or the regional seapower, Japan, as increasingly likely.

However, while geopolitical prediction is based on long-term cycles and trends, all trends eventually come to an end. The next section considers the extent to which, while the underlying conditions of the contemporary Northeast Asian subset bear a superficial resemblance to those of Europe in the first half of the twentieth century, a radically different strategic operating environment and geopolitical codes of the actors concerned may nevertheless lead to a very different prognosis. To paraphrase Alexander Wendt, geopolitics is what states make of it.

\section{A socially constructed perpetual peace?}

In the globalized world, many of the problems facing Northeast Asia are likewise global rather than regional in nature. Multifaceted complex interdependence rather than regional economic interdependence has changed the playing surface. Economic malaise, terrorism, weapons proliferation (both nuclear and conventional), drug and human trafficking, environmental degradation, climate change, AIDS, SARS, avian influenza, contaminated food products, smuggling, counterfeiting, and piracy all play a role in stimulating rational cooperation.

The rise of China and other great powers will end the United States' unipolar moment, but may also signify the end of the hegemonic cycles and hegemonic form of world leadership which has dominated international politics for the last 500 years. The end of the U.S.-American century need not lead to a Chinese, Japanese, Russian, or European century, but rather to a global form of governance or hegemonic alliance within which one or more Northeast Asian state will play an active role. Repeated economic and strategic interaction, and the recognition by ruling elites of the permanence and importance of these processes, can lead to the evolution of rules for avoiding unwanted conflicts and for facilitating desired exchanges. Failure to do so would mean an enormous inconvenience and, more seriously, potential loss of competitive advantage for those who failed to take this step when others had done so. So rationally, international order could evolve functionally in Northeast Asia from the logic of anarchy without preexisting cultural bonds found in Europe, but in direct reaction to the challenges posed by an increasingly integrated European and Atlantic bloc.

The geopolitical codes (practical output of geopolitical reasoning) of Northeast Asian states reflect the rational imperative to come to an accommodation with one another in order best to deal with the challenges they face. China's peaceful rise paradigm asserts thriving economically in a peaceful environment and also serving as a catalyst for peace, a kind of virtuous cycle maximizing China's economic benefit Hence in 2004, Premier Wen Jiabao said China's rise "will not come at the cost of any other country, will not stand in the way of any other country, nor pose a threat to any other country." ${ }^{28}$ Nowhere has China's attempt to project its peaceful rise paradigm been more apparent than in Asia. Economic relations with every country in the region have increased dramatically, and China has now surpassed the United States as the largest trading partner of both South Korea and Japan. Since the 1997 crisis, when China refused to devalue its currency, leading ASEAN Secretary General Rodolfo to announce "China is really emerging from this smelling good," 29 China has been playing the role of a responsible and even benevolent regional great power.

Japan, since the Yoshida Doctrine in response to anti-Japanese riots, has placed the highest priority on economic development, while simultaneously keeping a low diplomatic profile. Despite external and internal pressures for normalization recent polls (Nikkei Shimbun Opinion Polls, December 2007 and January 2008) found only 39 percent of respondents supported the renewal of the law permitting the dispatch of the Maritime Self Defense Forces to the Indian Ocean in support of antiterrorism measures in Afghanistan; and only 35 percent in favor of allowing the Self Defense Forces to be dispatched overseas. Yet there is continued support for the Japanese government to play a more active role in non-traditional areas of foreign and security policy such as the environment (Yomiuri Shimbun Opinion Polls 19 and 20 May 2007). Essentially there is support for a more independent pro-active Japanese security policy but not in line with a process of normalization which would require revision of Article Nine of the constitution, or would require Japanese troops to be put 
in harm's way.

Even the Korean peninsula can be seen as a rationally constructed zone of peace. North Korean leader Kim Jong-il clearly desires reunification of Korea, but knows he cannot expect to achieve the unification dream through an invasion which if not immediately halted, would soon be reversed by South Korea and her allies. The only unification achieved as a result of such tactics would be under a Seoul-based regime over the bodies of tens of thousands of Koreans from both sides. Kim has repeatedly asked for a non-aggression pact and recently won a significant diplomatic victory by having North Korea removed from the United States' list of terrorist-sponsoring states, and is interested in learning from past mistakes and changing for the better. ${ }^{30}$

Likewise, no matter how harsh the rhetoric, the current South Korean regime could never contemplate reunification by force. While much is made of the dangers posed by North Korea's missile and nuclear programs, the huge conventional artillery batteries currently massed in easy range of Seoul are more than capable of reducing the target to rubble at a fraction of the cost of developing a nuclear program, and with more certainty and efficiency than is currently demonstrated by the North's missile program. Any victory achieved by the South would be at best a pyrrhic one. In fact, the political and economic difficulties facing any attempt to reunify the Korean peninsula mean that an uneasy status quo is likely to endure for some time to come. Lee Myung-bak's aggressive stance has contributed to his recording the lowest-ever opinion poll ratings, which in turn have made it harder to take any definitive action.

All the major players have shown restraint in both their strategic interactions, and their economic policies in response to the current financial crisis. Far from reverting to the sort of beggar-thy-neighbor policies which exacerbated Europe's twenty year crisis, the United States, Japan, China, South Korea, Taiwan, and even Russia have embarked on cooperative financial stimulus plans, and international financial organization oversight culminating in agreement at the April 2009 meeting of the G-20 economies (which included most of the Northeast Asian subset) which has been called a London Consensus. ${ }^{31}$ In addition, rather than austerity packages or military-industrial stimulation of the economy, individual governments in the region seem more intent on new deals of public works. The Japanese government has recently announced a US\$15.4 trillion yen spending plan, the third in six months, bringing total spending to about 3 percent of gross domestic product. The Korean government announced a record 28.9 trillion won extra budget. China has announced a US\$600 billion stimulus package, with US\$25 billion offered to neighbors. The United States has pledged US\$787 billion stimulus package and proposed a US\$3.6 trillion budget.

Conclusion

Contrary to the hopes of liberal optimists, economic interdependence, international organization, and democratic consolidation have not led to the evolution of a zone of peace in Northeast Asia similar to that in Europe, nor, due to the limited progress made on all three sides of the virtuous triangle in the region, are they likely to in the short or even medium term. Indeed, the regional great power rivalry and economic challenges faced in Northeast Asia, have more in common with the crisis of liberal internationalism faced in Europe in the first half of the twentieth century. However, despite superficial similarities to interwar Europe, there is hope that armed conflict can be avoided in Northeast Asia due to the underlying differences between the two security operating environments and the geopolitical codes of the major actors.

External challenges and internal rational payoffs in Northeast Asia have contributed to a socially constructed rational peace quite different from that which emerged in Europe in the twentieth century. The regime is neither as consolidated nor as stable as its contemporary European counterpart, but it is still more entrenched than the liberal peace of the twenty year crisis. Indeed, any security regime that is able to deal with so many conflictual forces, faces countless skirmishes and instances of sabre-rattling, and yet for five decades prevent the outbreak of serious hostilities between social and political entities harboring historical grudges and outright hostility toward one another, may be considered durable indeed.

Notes

Brendan Howe is Associate Professor of International Relations at the Graduate School of International Studies, Ewha Womans University, Seoul, South Korea. He may be reached at bmghowe@yahoo.co.uk.

1. For this article Northeast Asia consists of China, Japan, Russia, North and South Korea, and, where data permits, Mongolia and Taiwan, as well as the United States.

\section{Thomas (2001, p. 3).}

3. Primarily extracted from the World Bank, gross national income (GNI) per capita 2007, Atlas method and PPP\$ (2009). H stands for high income (>US\$37,566, PPP\$36,100), UMC for upper-middle income (>US\$6,987; PPP\$11,868), LMC for lower-middle income ( $>$ US $\$ 1,887$; PPP $\$ 4,543)$, and LIC for low income ( $<$ US $\$ 578$; PPP\$1,494). PPP\$ = purchasing power parity or international dollars.

4. Globalization Index Rankings (2007).

5. Gruenwald and Hori (2008).

6. Gamble (2006).

7. Lee (1996); Lim (1996). 
8. Buzan and Segal (1998, p. 107).

9. Cohen (2004).

10. Thomas (2001, pp. 29-35).

11. Buzan and Segal (1998, p. 107).

12. Dittmer and Brzezinski, as cited in Nau (2002, p. 165).

13. Whitehead (1996, p. 21).

14. Nau (2002, pp. 163-164)

15. Kurlantzick (2006, pp. 270-276).

16. Ramo (2004, p. 4).

17. Bremmer, Choi, and Kawaguchi (2005).

18. Evans-Pritchard (2009).

19. Moore (2008).

20. Evans-Pritchard (2008b).

21. Evans-Pritchard (2008a).

\section{Halligan (2008).}

23. Figures for North Korea, Mongolia, and Taiwan are not listed as they are not among the top-10 spenders. The rankings change (slightly) if SIPRI numbers are employed for 2007, but these older figures miss recent increases in Northeast Asian military expenditure and, due to the dramatic appreciation of the euro against the dollar and devaluation of the Korean won in 2008, also would drastically skew global rankings if converted to U.S. dollars at current exchange rates.

24. Mosher (2000, pp. 58-59).

25. BBC (2009).

26. Dupont (2005, pp. 43-44).
27. Calder (2006).

28. Pan (2006).

29. Pan (2006, p. 272).

30. Gregg (2003).

31. Kaufman (2009).

References

[BBC]. 2009. “Uncertain Future for Fractious Koreas.” BBC News. 30 January 2009. http://news.bbc.co.uk/2/hi/asia-pacific/7861114.stm [accessed 27 February 2009].

Beeson, M. 2009. "Hegemonic Transition in East Asia? The Dynamics of Chinese and American Power." Review of International Studies. No. 35, pp. 95-112.

Bremmer, I., S.H. Choi, and Y. Kawaguchi. 2005. "Northeast Asia: Defusing a Dangerous Region.” International Herald Tribune. 30 December 2005.

Buzan, B. and G. Segal. 1998. "Rethinking East Asian Security,” pp. 96-112 in M.T. Klare and Y. Chandrani, eds. World Security: Challenges for a New Century. New York: St. Martin's Press.

Calder, K.E. 2006. “China and Japan's Simmering Rivalry.” Foreign Affairs. Vol. 85 (March/April), pp.129-139.

[CIA World Factbook]. 2009. https://www.cia.gov/library/publications/the-worldfactbook/ [accessed 13 April 2009].

Cohen, R. 2004. "Talking Human Rights with North Korea." The Washington Post. 29 August 2004.

Cooney, K. 2007. Japan's Foreign Policy Since 1945. New York: M.E. Sharpe.

Dupont, A. 2005. “The Schizophrenic Superpower.” The National Interest. Issue 79 (Spring), pp. 43-51.

Evans-Pritchard, A. 2009. "Japan's Exports Collapse as Crisis Deepens in Asia.” The Telegraph. 26 February 2009. http://www.telegraph.co.uk/finance/financetopics/ recession/4807231/Japans-exports-collapse-as-crisis-deepens-in-Asia.html [accessed 27 February 2009].

Evans-Pritchard, A. 2008a. "World Stability Hangs by a Thread as Economies Continue to Unravel." The Telegraph. 1 December 2008. http://www.telegraph.co.uk/finance/comment/ambroseevans_pritchard/3537362/ World-stability-hangs-by-a-thread-as-economies-continue-to-unravel.html [accessed 27 February 2009].

Evans-Pritchard, A. 2008b. "Asian Trade in 'Fee Fall' as Exports to West Dry Up." The Telegraph. 10 December 2008. http://www.telegraph.co.uk/finance/finance topics/financialcrisis/3692255/Asian-trade-in-Free-Fall.html [accessed 10 


\section{December 2008].}

[Foreign Policy]. 2007. “Globalization Index Rankings for 2007.” http://www. foreignpolicy.com/story/cms.php?story_id=4030 [accessed 28 February 2009].

Gamble, W.B. 2006. “Chinese Economic Nationalism.” International Assessment and Strategy Center. http://www.strategycenter.net/research/pubID.130/pub_detail.asp. 12 December 2006. [accessed 25 May 2009].

[Globalissues.org]. 1 March 2009. http://www.globalissues.org/article/75/worldmilitary-spending\#InContextUSMilitarySpendingVersusRestoftheWorld [accessed 13 April 2009].

Gregg, D. 2003. "My Turn: Kim Jong Il - The Truth Behind the Caricature." Newsweek. 3 February 2003. www.cifor.cgiar.org/publications/pdf_files/media/ Newsweek-DK-0103.pdf [accessed 4 March 2009].

Gruenwald, P. and H. Masahiro. 2008. "Intra-regional Trade Key to Asia's Export Boom.” IMF Survey. http://www.imf.org/external/pubs/ft/survey/so/2008/ CAR02608A.htm [accessed 6 February 2008].

Halligan, L. 2008. "Doha Failure Denies the World Economy a much-needed Boost." The Telegraph. 22 September 2008. http://www.telegraph.co.uk/finance/comment/ liamhalligan/2794184/Doha-failure-denies-the-world-economy-a-much-needed -boost.html [accessed 28 September 2008].

Kaufman, D. 2009. "Who 'Won' in the London G-20 Summit?" Washington, D.C.: The Brookings Institution. 16 April 2009. http://www.brookings.edu/opinions /2009/0409_g20_kaufmann.aspx? emc $=1 \mathrm{~m} \& \mathrm{~m}=224148 \& \mathrm{l}=28 \& \mathrm{v}=729319$ [accessed 18 April 2009].

Kurlantzick, J. 2006. “China's Charm Offensive in Southeast Asia.” Current History. (September), pp. 270-276.

Lee, C.J. 1996. "Korea's Role in Northeast Asian Integration." Special issue: "Economic and Regional Cooperation in Northeast Asia." Joint U.S.-Korea Academic Studies. Vol. 6, pp. 237-238. [Korea Economic Institute of America, Washington, D.C.].

Lim, Y.C.L. 1996. "Whither Northeast Asian Regional and Economic Cooperation." Special issue: "Economic and Regional Cooperation in Northeast Asia." Joint U.S.-Korea Academic Studies. Vol. 6, pp 234-236. [Korea Economic Institue of America, Washington, D.C. ].

Mosher, S.W. 2000. Hegemon: China's Plan to Dominate Asia and the World. San Francisco: Encounter Books.

Moore, M. 2008. "Financial Crisis: Asian Shares Slump Again." The Telegraph. 8 October 2008. http://www.telegraph.co.uk/finance/financetopics/financialcrisis /3156286/Financial-crisis-Asian-shares-slump-again.html [accessed 27 February 2009].

Nau, H.R. 2002. At Home Abroad: Identity and Power in American Foreign Policy. Ithaca, NY: Cornell University Press.

Pan, E. 2006. "The Promise and Pitfalls of China's 'Peaceful Rise'." Council on
Foreign Relations. 14 April 2009. http://www.cfr.org/publication/10446/ [accessed 19 January 2008].

Ramo, J.C. 2004. The Beijing Consensus. London: The Foreign Policy Centre.

Thomas, D.C. 2001. The Helsinki Effect. Princeton, NJ: Princeton University Press.

Whitehead, L. 1996. The International Dimensions of Democratization: Europe and the Americas. New York: Oxford University Press.

[World Bank]. 2007. "Gross National Income per Capita." http://siteresources. worldbank.org/DATASTATISTICS/Resources/GNIPC.pdf[accessed 27 February 2009]. 